\title{
The Impossibility of
}

\section{a Defence Policy in the Americas? Comparing Hemispheric and South American Security Concepts and Military Roles}

\section{Marina Gisela Vitelli ${ }^{*}$}

\begin{abstract}
This article analyses the competing security perspectives of hemispheric and South American defence cooperation initiatives. While the Organization of American States (OAS) emphasises domestic roles for armed forces in the region, concentrating on internal threats such as organised crime and terrorism, the South American Defence Council (CDS) emphasises the traditional conception of security, concentrating on the defence of sovereign states against external military threats. Despite its apparent consistency, the concept of deterrent cooperation has not taken hold. While the literature interprets this failure as a cooperation problem, I argue that it is due to a deeper regional trend, namely the tendency to neglect external defence in favour of internal security roles for armed forces. After building a conceptual framework for clarifying these divergent perspectives, I show how they define the activities of the two competing organisations. Next, I address the conflict between the CDS's conception of security and the security policies of OAS member states. Finally, I discuss domestic and structural obstacles to the adoption of common Latin American defence policies.
\end{abstract}

Keywords: South America; defence; security; military missions; new threats.

\section{Introduction}

During the 1990s, debates about security perspectives took place in both existing and newly created western hemispheric forums, particularly the Organization of American States (OAS). These discussions reflected a transitional regional scenario: a virtuous circle of democracy and regional integration was facilitating the peaceful resolution of most existing interstate disputes, as well as the introduction of bilateral security cooperation ini-

Federal University of São Paulo (UNIFESP) and San Tiago Dantas Graduate Program (UNESP-UNICAMPPUCSP), São Paulo-SP, Brazil; marinagvitelli@gmail.com. ORCID iD 0000-0001-8827-6279. 
tiatives. Also, with the end of the Cold War and the defeat of armed political organisations, the external-internal threat of communism was terminated, and only local manifestations of leftist insurgencies persisted. Latin American countries supposedly had nothing to fear from either intra-regional wars or foreign enemies. This prompted the question of how security should be conceived in a post-Cold War, post-authoritarian hemisphere, and, as a consequence, what roles the armed forces should play.

At the same time, organised crime was rapidly gaining in power and complexity, looming over society and, according to some, over the state (Bartolomé 2013; Realuyo 2015). Drug cartels were responsible for an escalation of violence and the corruption of state authorities, while guerrilla organisations began financing their political activities through illicit trafficking, kidnappings, and other violent means usually employed by terrorist groups. Based on this narrative, as the $20^{\text {th }}$ century ended, the OAS promoted a new security agenda for the hemisphere under the rubric of 'multidimensional security' that focused on combating 'new threats', particularly drug trafficking and other types of transnational organised crimes (Saint-Pierre 2012; Soares and Mathias 2003; Tickner and Herz 2012). After the terrorist attacks of $9 / 11$, the focus on non-traditional security threats intensified (Duarte Villa 2014).

While many countries followed this security script and supported the hemisphere's novel conception of security, other resisted the new doctrine, even while selectively applying it at home (Mathias et al 2016; Soares and Camargo Lima 2013). The establishment in 2008 of the South American Defence Council (CDS) as part of UNASUR expressed this disagreement over whether the subregion was actually free from military coercion by a superior extra-regional power, and whether abandoning strategic thinking about traditional threats was a reasonable choice. As I have argued elsewhere, by attempting to develop an alternative strategic concept of 'deterrent cooperation', the CDS confronted the multidimensional security perspective focused on employing the military for mostly domestic security-related missions. By contrast, the CDS - as evident from much of its activities, as well as from approved documents - sought to formulate a strategic regional identity centred on potential threats to natural resources by extra-regional, more powerful enemies, and on cooperation as a regional strategy for protecting those common assets (Vitelli 2016b). In the process, in contrast with OAS initiatives, this South American institution appears to have reclaimed the need to think about national security in traditional geopolitical terms, a perspective associated with external defence rather than security issues involving transnational non-state actors.

Given that a hemispheric security concept centred on fighting drug trafficking and terrorism clearly reflects US national security interests, a South American concept critical of those priorities may reinforce the belief that the CDS is an anti-American organisation. However, scholars have argued that the CDS was not conceived as a direct threat or competitor to the OAS system, in part because Brazil (the main proponent of the CDS) had no interest in confronting the USA only to foster regional peace and stability as means of attaining a more relevant goal, namely its regional leadership (Soares 2011; Spektor 2010). Together with other factors - such as Argentina's incompatibility with the Venezuelan agenda of collective defence (Frenkel and Comini 2017), and the lack of consensus among 
countries related to their relations with the USA (Vitelli 2016b), the CDS did not explicitly antagonise hemispheric security institutions.

On the other hand, after seven years of significant progress, the CDS lost vigour and, by 2016, had drastically reduced its activities in the context of the broader crisis besetting UNASUR as a whole (Nolte and Mijares 2018). A different set of obstacles explains its current paralysis. Some scholars have stressed Brazil's reluctance to become a paymaster (Malamud and Rodriguez 2014; Fuccille 2016; Nolte and Mijares 2018), while others point to unbridgeable differences in strategic identities (Medeiros Filho 2013, 2017) as well as transformations in the regional balance of power (Vaz et al 2017). While those are all compelling accounts of the limitations of South American cooperation in the defence realm, we believe the literature has neglected a deeper trend that affects the security approaches of Latin American countries, particularly their definition of the roles of the armed forces. The tendency to move away from defence policy towards domestic security grants the region its specificity in the security realm, and creates a contradiction for the CDS's attempt to formulate a strategic identity centred on external defence. The debate about regional security cooperation - including assessments of the CDS - has often overlooked the role of this factor in impeding defence cooperation in a relatively homogenous region.

Against this background, this article offers an analysis of current Latin American security dynamics, with a twofold purpose. The first is to stress a distinctive feature of security in the region: while the defence policies of countries in Europe, Asia, and Africa reflect concerns with a combination of geopolitical tensions, great power rivalry, internal political strife and counter-terrorism, Latin American policies have relinquished a fair part of traditional defence roles in favour of internal security issues. The second is to illuminate the way in which this trend has impacted on regional security cooperation initiatives. Therefore, I argue that hemispheric and South American security institutions do compete in the quest to define regional strategy: the former favours internal security, while a considerable part of the latter's actions and statements refer to external defence. ${ }^{1}$ However, those countries that adopted the latter perspective failed to convince others which had reluctantly acquiesced or not actively opposed to the traditional conception of defence in outward-facing terms - a key factor in making sense of the CDS's current paralysis. Therefore, more than a cooperation problem, this institution confronts a disjunction with the current Latin American security perspective, and the policies fashioned after it.

The article begins by presenting the link between threat assessment and military roles in both the OAS's concept of multidimensional security as well as the CDS's notion of deterrent cooperation. Secondly, it shows how these two competing views were expressed in the initiatives of both Hemispheric and South American defence and security cooperation institutions. In the first instance, we will look into how the multidimensional security concept permeated the reform of OAS security institutions: the Commission on Hemispheric Security (CHS), the Inter-American Defence Board (IADB) and College (IADC), and the William J. Perry Center for Hemispheric Defence Studies (Perry Center), which, despite being a US government institution, has been a centrepiece of defence initiatives in the region. As regards South America, we will examine the CDS's main activities, and particularly its courses, offered at its Centre for Strategic Defence Studies (CEED) and Defence 
School (ESUDE), stressing the way in which external defence roles for the armed forces have been emphasised.

Next, the article confronts CDS attempts to focus on external defence issues with actual policies pursued by individual member states that rely on the military for public security missions, in order to stress this fundamental contradiction. To conclude, I discuss domestic and structural factors that may account for the apparent impossibility of adopting a common defence policy in Latin America.

\section{Security concepts and military roles in Latin America}

When the Cold War ended, the global trend towards a radical change in security perspectives coincided with Latin America's urgent need to reform the OAS, after this organisation's failure to broker negotiations for the resolution of the Central American conflict. In 1991, in an attempt to restore its legitimacy as a regional peace and security institution, OAS members created the Special Commission for Hemispheric Security, which four years later was transformed into a permanent commission within the OAS Permanent Council, namely the CHS. At the same time, the USA sponsored the first Defence Ministerial Conference of the Americas (CMDA), starting in Williamsburg and reassembling in Bariloche the following year, where US Defence Secretary William J Perry proposed the creation of a defence studies centre ${ }^{2}$ which was inaugurated in September 1997. Therefore, despite being proposed and discussed at a hemispheric event, the Perry Center is a US Defence Department institution, associated with its National Defence University, and connected to the US Southern and Northern Commands.

Following discussions at the CDMAs, the OAS sponsored a Conference on Hemispheric Security in Mexico City in 2003. This resulted in three relevant innovations: the official formulation of the concept of multidimensional security, a recommendation to create a Multidimensional Security Secretariat (MSS), and a decision to establish formal relations with two pre-existing defence institutions: the IADB and its College, which in 2006 became an entity of the OAS.

The Declaration of Security in the Americas approved in Mexico City expressed a change in perceptions of regional threats to security as well as the referent objects when it declared: 'Our new concept of security in the Hemisphere is multidimensional in scope, [and] includes traditional and new threats, concerns, and other challenges to the security of the states of the Hemisphere.' The Declaration then referred to the human security perspective when it claimed that the 'rationale and raison d'etre of security are the protection of the human being, signalling an apparent revolutionary transformation: the individual and not the state is the main recipient of security-related concerns. Since the region's peo-

ple were more affected by gang violence, organised crime, natural disasters and poverty, it seemed to make sense to prioritise non-state domestic issues instead of interstate strategic and military disputes. In fact, despite acknowledging the relevance of traditional threats, the document only listed new ones, starting by those related to direct violence - such as terrorism, transnational organised crime, the global drug problem, corruption, money 
laundering and illicit arms trafficking - and continuing with manifestations of structural violence, namely poverty, social exclusion, natural disasters, endemic illnesses, cyber security, environmental accidents, and the proliferation of weapons of mass destruction. The emphasis on social issues and non-coercive policy instruments obscured the fact that the notion of multidimensional security stimulated the participation of both military and security forces in dealing with non-traditional threats.

As I have shown elsewhere (Vitelli 2016a), some countries, particularly Argentina and Brazil, resisted the OAS's redefinition of regional security under the multidimensionality rationale, and excluded it from the South American security organisation established in 2008. Examining views of the CDS's imperfections and limitations, I have shown that the original intention was to create a forum dedicated to producing alternative strategic thinking about hemispheric understandings of regional security. In this way, and regardless of the extent to which it succeeded, thinking, debating, teaching and learning were featured as relevant cooperation practices inside the CDS (Vitelli 2017). In order to address the task of crafting a security concept of its own, the CDS created the CEED as a permanent unit for research and strategic thought, and, in 2014, established an educational institution in respect of defence issues - ESUDE - aimed at coordinating existing and future educational cooperation on security.

Despite initial uncertainty about what type of regional cooperation organisation the CDS would be - a crisis management mechanism, like the UN Security Council, a military alliance with a collective security arrangement, or a less ambitious forum for political coordination - UNASUR members agreed to limit CDS functions to consultation, cooperation and concertación (Merke 2015). In this way, the CDS was not granted significant autonomy nor sufficient resources to radically influence members' defence policies, which detracted from its chances of creating a successful security concept of its own. However, instead of focusing on the institutional weaknesses and limitations of regional institutions, ${ }^{3}$ a relationship persisted between pre-existent security and defence conceptions and attempts by these institutions to create one. In this sense, the fact that so much emphasis was placed on the CDS as a forum for dialogue about regional security - an allegedly minor function - indicates that the very understanding of what security meant for South Americans was identified as a point of divergence, an object of contention both between ideologically opposing views - namely Colombian and Venezuelan - and between countries that opposed the multidimensional security concept and those that favoured it.

Barely six months after its establishment, the CDS was challenged by a diplomatic crisis generated by the signing of an agreement between Colombia and the USA to update their military cooperation. The July 2009 accord featured a surge in the US military presence on Colombian soil, causing apprehension among Bolivarian countries. and discomfort in Argentina and Brazil. Although UNASUR's heads of states were summoned to Bariloche to ease the tensions, the CDS did play a part in subsequent efforts to neutralise conflicting views of regional security dynamics. The heads of state requested the CEED to draft a consensus document on security concepts, specifying what UNASUR understood by 'Defence' and 'Security'. Far from being a trivial, academic discussion, it raised a vital 
question: what was the military concern of South America's pre-eminent institution for defence cooperation? The result was a document that identified and examined heterogeneous security concepts in the subregion, and produced the consensus that, as far as the CDS was concerned, defence meant the countering of extra-regional threats (CEED 2012). However, political insurgence and organised crime were not overlooked - the report also proposed the creation of a separate organisation to deal with the most relevant 'new threats' - later supplemented by a third security-related institution, dedicated solely to the global drug problem. The case was made that multidimensional security issues needed to be treated separately from traditional military ones. ${ }^{4}$

In sum, while security institutions forming part of the hemispheric system advocated a notion of regional security focused on threats from non-state actors within the region, the CDS stressed state-level threats from outside it. These two conceptions imply very different armed forces as instruments to counter those threats, offering fundamentally divergent answers to the question: 'What do we need the armed forces for?' While advocates of multidimensional security envisage the armed forces acting primarily in respect of domestic security, the CDS supports the idea of militaries designed to deter attacks by extra-regional hostile states.

The connection between threat assessment and force design can best be explored by using Shemella's (2006: 123) framework of five different military roles, defined as the 'broad and enduring purpose(s) provided by (political authorities) to each branch of the armed forces.' First, the armed forces of War Fighter countries are principally designed to fight offensive wars for the purpose of the settlement of international disputes. Second, the military forces of Defender countries 'are presumed to exist primarily for response to an armed attack from within the region' (Shemella 2006: 123). Third, Peacekeepers are countries with armed forces dedicated to peace support operations, while Fire Fighters use their armed forces for diverse purposes in the domestic realm, except the performance of law enforcement on a regular basis. These include the development of infrastructure, crisis management, and, in some cases, fighting insurgencies or civil wars. Finally, Police Officers are countries with armed forces whose main role is law enforcement. While in the former the armed forces and police work together, in the latter the military has openly replaced police forces (Shemella 2006: 126-127).

Multidimensional security is a hybrid of Fire Fighters - dealing with issues of social and structural violence - and Police Officers, dealing with problems related to internal violence. The articulation of both armed force 'brands' represents the repurposing of the armed forces implicit in the hemispheric security logic. By contrast, 'Defender' is closest to the deterrent cooperation concept envisioned for the South American armed forces, though a series of adaptations are in order. First, Shemella circumscribes potential attacks from countries in the same region, while the CDS concept referred to extra-regional threats. The first option is ruled out by the existence of confidence-building measures and other cooperative security policies. Secondly, by referring to examples such as Taiwan and South Korea, the author argues that, 'for poor strategic circumstances or unusual political situations,' Defender countries are 'constrained from preparing their military forces for offensive operations.' In contrast, it has been argued that Latin American countries, even 
regional powers such as Brazil, lack strategic culture traits that make offensive use of force an alternative. Thirdly, it is necessary to supplement the author's claim that the armed forces of Defender countries are designed to respond to attacks with a previous scenario explicitly featured in the deterrent cooperation concept: dissuading external forces from hostile action.

Drawing on Shemella's (2006) conceptual framework, the remainder of this article sequentially analyses hemispheric and South American security initiatives in order to identify the main features of their security concepts and the correspondent roles for the armed forces, as a precursor to discussing the impact of a mismatch between the CDS's deterrent cooperation perspective and the actual policies of member states. For this purpose, the Defender role is associated with functions and activities dealing with themes such as the strategic assessment of international trends in terms of power relations and potential conflicts of interest that could end in extended armed conflicts, as well as chances of confronting threats to two core interests: territorial integrity and national sovereignty. By contrast, the multidimensional blend of Fire Fighter and Police Officer is connected to the activities of non-state transnational actors, particularly drug, human and arms trafficking, gangs, and natural disasters.

\section{Hemispheric institutions: reforms under the notion of multidimensional security}

As noted in the introduction, the restructuring of the OAS after the 2003 Mexico Conference reinforced the multidimensional security perspective. ${ }^{5}$ In 2005 , as a follow-up to the new concept of security formulated in the Declaration of Security in the Americas, the OAS created the Secretariat for Multidimensional Security within the General Secretariat. The MSS brought together the work of two existing commissions: the Inter-American Drug Abuse Control Commission (CICAD), and the Inter-American Committee against Terrorism (CICTE). Moreover, a Department of Public Security (DPS) was created under the MSS authority, which could suggest a division of labour in which this new Secretariat would work with issues related to new threats, while the CHS would address traditional threats and other matters of peace among states. To the contrary, the CHS incorporated a series of issues that expressed countries' concerns about crime, public safety, drug trafficking, and related problems. Indeed, CHS reports deal with issues related to two agendas: on the one hand, a concern with intraregional peace expressed by the cooperative security vision, emphasising the need to build trust and transparency to ensure peaceful relations between member countries; and on the other, a multidimensional security agenda centred on new threats, including public security; transnational organised crime; trafficking in persons, small arms, and drugs; and the problem of gangs.

The first agenda comprises decisions and activities dealing with confidence-building measures, cooperation with non-proliferation regimes of weapons of mass destruction, and transparency in the acquisition of conventional weapons. While these issues belong to the state-centred vision, they do not fit into the 'Defender' role for the armed forces, due to the absence of references to extra-regional military threats. In fact, there is no CHS report 
that deals with this type of threat, either the security implications of geopolitical dynamics and shifts in global power, the potential ramifications of strategic natural resources disputes, or the security implications of the Iranian and North Korean nuclear programmes.

By contrast, activities related to multidimensional security and public security roles for the armed forces are prominent. I will now mention some examples, while a complete list appears in Table 1. First, in 2008 the CHS began organising the Meetings of Ministers Responsible for Public Security in the Americas (MISPA). Despite the existence of a specific institution to deal with public security - the DPS - all seven meetings held between 2008 and 2017 were led by the CHS instead of the DPS, including negotiating the agenda and drafting the negotiating documents. Second, the CHS was also involved in the fight against transnational organised crime. In 2007, the commission created a Technical Working Group which met four times until 2013, when it approved a Work Plan against Organized Transnational Delinquency. Trafficking in persons also received attention from the Commission, including the organisation of four Meetings of National Authorities on Trafficking in Persons, and the drafting - in cooperation with the DPS - of two Work Plans (2010-2012 and 2015-2018).

Since 2005, the CHS also systematically addressed the issue of trafficking in small arms, including the negotiation of an inter-American convention. Finally, in 2009 it created a Working Group for preparing a regional strategy to promote inter-American cooperation in dealing with criminal gangs. The document was drafted in collaboration with the DPS, but the active participation of the Commission should be noted, indicating that the issue falls under the scope of the CHS.

In 2006, the IADB - founded in 1942 - was transformed into an OAS entity. Since then. it has adopted roles associated with the traditional and contemporary dimensions of defence. The IADB's most recent report for the period 2015-2016 attests to its participation in issues related to cooperative and multidimensional security, with no trace of a Defender role as defined in this article.

In terms of regional cooperation, the IADB has been given the role of liaising with and among the military forums and conferences of Latin American military forces, as well as the CMDA. While its intermediating role with military conferences is reasonable, its technical consultancy role to the Pro Tempore Secretariat of CMDA is more controversial, since these bi-annual forums have fully adopted the multidimensional security agenda (Donadelli 2016), thus directly connecting a military institution with issues of internal security. Additionally, the IADB plays a role in the hemispheric system devised to systematise information about confidence-building measures, since national authorities are meant to send the reports requested by the OAS Secretary General through IADB delegations.

On the other hand, other attributions show that, since its transformation, the IADB has increased its participation in issues related to domestic military roles. First, natural disaster assistance - a key feature of the role of Fire Fighter countries - has risen on the agenda of the renewed IADB. The 'new threats' of organised crime and terrorism also feature in the Board's activities. For example, the IADB took part in Sovereign Challenge 14 , a forum on extremist terrorism in the USA, featuring the participation of 38 countries, 
including some from outside the Hemisphere. Similarly, the Board was an observer at the Ninth Summit of AMERIPOL, a meeting of representatives of police forces in the region to discuss various forms of terrorism. Finally, the IADB participated in the Working Group on Cyber Crime set up for the Meeting of Ministers of Justice, Prosecutors and Attorneys General of the Americas.

Founded in 1962 as an associate entity of the IADB, the Inter-American Defence College has a long history of training the military in the Hemisphere. In 2014 it was certified by the Accrediting Council For Independent Colleges And Schools (ACICS), and transformed one of its courses in a master's degree ${ }^{6}$ aimed at '(preparing) individuals to assume senior strategic-level positions within their governments' as a result of gaining 'in-depth understanding of the regional defence and security related disciplines' (IADC 2016). The master's syllabus is based on the OAS's four pillars: Democracy, Human Rights, Integral Development, and Multi-Dimensional Security. Moreover, this course is not only intended for military and civilian government officials serving in the Defence Ministry, but also for national police officials, another indicator that the multidimensional security perspective is present. Moreover, according to the 2016 IADB Report, the IADC is considering the introduction of another master's degree dedicated entirely to multidimensional security (IADB 2016).

The course programme deals with both external defence and internal security. The first is present in subjects such as the conceptual differences between security and defence; strategic thinking for hemispheric defence and security; geopolitical assessment of world regions; conflict analysis and resolution; and peace support operations. In fact, and contrary to what could be expected from the inter-American flagship defence institution, the master's degree features only one course on 'Multidimensional Security in the Americas: Challenges, Threats and Responses.' In the case of elective courses, no traditional external defence option is offered, though only one of a total of seven - illicit economy - belongs to the multidimensional agenda. ${ }^{7}$

As noted earlier, even though the Perry Center is a US regional centre for security studies rather than an OAS institution, no account of hemispheric defence cooperation would be complete without taking it into consideration. After 20 years of existence, it has pioneered hemispheric cooperation in the post-Cold War period in three areas: education, advising states on defence and security policy formulation, and outreach. The last category includes ongoing discussions of security challenges and the means to counter them among a network of alumni.

After analysing the available information, ${ }^{8}$ I could not find a single course that dealt specifically and exclusively, or even fundamentally, with issues related to the traditional defence perspective. Two older courses - Strategy and Defence Policy (SDP) and Caribbean Defence and Security Course (CDSC) - examine a range of defence issues, but not exclusively nor primarily. SDP - the only course that has been offered non-stop since the Perry Center's establishment - is an introductory course, covering issues such as defence and security policy formulation and implementation, resource management, civilian-military and law enforcement cooperation, defence economics, interagency and international coordination, and control and oversight. However, these traditional defence subjects share 
the syllabi with non-conventional issues such as support missions for security forces, multidimensional challenges and threats, transnational threats, and organised crime, as listed in Table 1.

In summary, the agendas of these forums have increasingly featured topics related to multidimensional security - particularly the fight against organised crime and its corresponding Police Officer military role- articulating the securitisation and socialisation process of Latin American civil and military officials in relation to the militarisation of policies to combat new threats. Meanwhile, activities regarding traditional defence are practically non-existent. No evidence was found of any kind of activity - either political or educational - dealing with the Iranian and North Korean nuclear programmes, or the security implications for the region of the growing need for natural resources by China, Russia, and other emergent powers.

Table 1: The activities of hemispheric security institutions

\section{Multidimensional security agenda - internally focused military missions}

1. Commission for Hemispheric Security

- Meetings of Ministers Responsible for Public Security in the Americas.

- Working Group to prepare a Hemispheric Plan of Action to Follow-up on the Declaration of San Salvador on Citizen Security in the Americas.

Technical Working Group for the drafting of a Work Plan against Organized Transnational Delinquency. Meetings of National Authorities on Transnational Organized Crime.

Meetings of National Authorities on Trafficking in Persons.

Inter-American Convention against the Illicit Manufacturing of and Trafficking in Firearms, Ammunition, Explosives, and Other Related Materials.

Working Group to Prepare a Regional Strategy to Promote Inter-American Cooperation in Dealing with Criminal Gangs.

2. Inter-American Defence Board

- Pro Tempore Secretariat of Conference of Defence Ministers of the Americas (multidimensional security agenda).

- $\quad$ Observer at the 9th Summit of AMERIPOL (Community of American Police).

- 'Sovereign Challenge 14', a forum on extremist terrorism in the United States.

- Working Group on Cyber Crime set up for the Meeting of Ministers of Justice, Prosecutors and Attorneys General of the Americas.

3. Inter-American Defence College

- Master's degree: Democracy, Human Rights, Integral Development, and Multi-Dimensional Security.

- Master's degree on Multi-Dimensional Security (forthcoming).

4. Perry Centre courses

- Strategy and Defence Policy

- Caribbean Defence and Security Course

- Combating Transnational Organized Crime and Illicit Networks

- Interagency Coordination and Combating Terrorism

- Perspectives on Homeland Security and Defence ${ }^{9}$

- Governance, Governability, and Security in the Americas

- Terrorism and Counterinsurgency

Source: Developed by the author. 


\section{South American institutions: outlining deterrent cooperation}

The CDS's activities differ fundamentally from those of its hemispheric counterparts. From 2009 until 2015, it held more than 60 working meetings and 32 workshops, seminars, symposiums and conferences, ${ }^{10}$ dealing with a diverse range of topics though to be relevant to South American defence. They encompassed various topics related to the external defence agenda, including defence policy, strategic planning, national mobilisation, strategic military intelligence, defence and natural resources, the monitoring of special areas, cyber threats, and airspace control. The seminars and meetings also discussed guidelines for a common conceptual framework for defence and security. Furthermore, South American countries addressed the issue of industry and technology for defence, including two joint projects, namely the construction of a training aircraft and an unmanned aerial vehicle.

The CDS also dealt with cooperative security issues, such as confidence-building measures, human rights, humanitarian law, and the drafting of a peace protocol. Fire Fighter activities included cooperation on natural disaster relief, and Peacekeeper activities included peace operations in general and the UN stabilising mission in Haiti in particular. By contrast, no issue pertaining to the public security dimension of multidimensional security - particularly organised crime and terrorism - was a main topic at any of the CDS working groups or seminars.

The CEED - meant to be the CDS's strategic think-tank - organised a number of activities and published documents that expressed the prioritisation of external defence and the isolation of issues of multidimensional security. s stated in a previous section, it was CEED staff who drafted the conceptualisation document that differentiated defence from security. CEED also led the process that produced Prospective Study South America 2025, which contained an extensive analysis of the region's natural resources, as well as global trends that may affect them. Additionally, CEED's first executive director, Alfredo Forti (2014), authored a paper that helped formulate and publicise the deterrent cooperation concept.

While CEED deals with strategic thinking, other activities focus on education on defence issues, which is viewed as a confidence-building measure as well as a tool for consolidating civilian leadership of defence policy, one of the goals set by South American countries when they negotiated the CDS statute. Every action plan includes a section on 'Formación y Capacitación,' which can be translated as education and training. To accomplish the specific goal of fostering education and military training exchange, the CDS first introduced two courses: the Advanced Course for South American Defence (CAd-Sul), and the South American Defence Education course. Some years later, in 2014, it established its South American Defence School.

CadSul, organised by the Brazilian Escola Superior de Guerra following authorisation by the CDS, is a ten-week course presented in Rio de Janeiro every year since 2012. Each country is invited to send two students, and can send more as long as it pays their expenses. Syllabi - though slightly adjusted in successive syllabi - deal with diverse issues of regional and international politics and security, such as South-American integration, multilateral cooperation organisms; international and humanitarian law order; South America in the 
world geopolitical scenario; peace operations; cyber defence; managing and monitoring special areas in South-America; defence industry; confidence-building measures; gender perspectives, and the restructuring of South American defence thinking.

While Cad-Sul does not include topics related to multidimensional security, particularly combating organised crime, a rather different observation was possible when I attended two Cad-Sul classes in October and November 2016. After taking part as an observer and conducting interviews with instructors and informal talks with participants, it was brought to my attention that the decision to exclude multidimensional topics was not unanimous. Controversies among students over military missions - the core issue behind multidimensionality - are common, confronting countries that agree to a militarised fight against drug trafficking on the one hand, and those that oppose it on the other.

A similar experience, although more limited in terms of face-to-face interaction, was the CDS's South American Defence Education course. It consisted of a graduate-level distance educational experience organised yearly from 2012 until 2015 by the Argentinean defence ministry. It was directed at civilian personnel dealing with defence issues, as well as active or retired military officials selected by the defence ministry of each country. Additionally, candidates obtaining the highest grades in each delegation were invited to take part in a week-long resident phase in Buenos Aires. Course contents remained roughly the same throughout all four syllabi. In 2012 and 2013. subjects were organised into five modules: Society, state, government and defence; Civil-military relations; Defence as public policy; International Security and Defence; and Armed forces. The 2014 syllabus significantly altered the course content by introducing new subjects - strategic planning, natural resources and defence, human rights and gender issues and regional security. In 2015, the only modification was the exclusion of the topic on natural resources. Similarly to CadSul, multidimensional security topics were excluded from the curricula.

In 2014, CDS members created ESUDE, an institution meant to form the core of an academic network in charge of facilitating cooperation among existing military education institutions in each country, aimed at enhancing exchange opportunities. In 2016, it started its first virtual course titled 'South America in the International Security Context' (ESUDE 2016). This graduate-level course consists of five modules that will be offered in the near future, depending on resources. Each module examines important aspects of the 'the understanding of South America in contemporary international security' (ESUDE 2016).

A series of features suggests that the course falls under the rubric of traditional defence roles. First, its central objective is 'to examine the current security scenario from the point of view of South America's involvement at an international level,' stressing a general view of international, external security dynamics. Following the same logic, the course description states that students are expected to discuss 'the main current international political processes and their implications for the region's defence, as well as 'the basis for the construction of a common regional defence identity' (ESUDE 2016).

Given that the course has a flexible design, the syllabus acknowledges that national defence institutes offer additional modules or suggest modifications of current ones, always under the supervision of the school's director. The aim is to provide an opportunity 
for countries to develop a 'shared regional perception of the challenges and threats it faces in the international security arena.' The last two modules can be chosen from a list of subjects: cyber defence, immigration, the geopolitics of natural resources, natural disaster responses, human rights, gender and the armed forces, and mediation and conflict transformation. The fact that transnational crime and terrorism - the two more controversial 'new threats' - are absent from the list is a sign that it seeks to avoid multidimensional security topics, even when other non-traditional military issues are listed.

The initial module structure presented on the ESUDE website lists various topics that belong to the defence agenda, such as contemporary international security scenarios, the historical determinants of South-American insertion into the international scenario: political, socio-economical and strategic aspects; and South America in global geopolitics and its cooperation challenges in strategic intelligence (ESUDE 2016). Furthermore, in 2017, the course started its first module entitled 'Contemporary international security scenarios: implications for a regional security and defence perspective, also heavily influenced by an agenda concerned with geopolitical issues, among them prospective world scenarios, horizontal risks affecting every country, regional tensions and potential interstate conflicts, topics that could 'destabilize international relations and create problems in the defence realm,' and the examination of 'international dynamics in the security realm' (ESUDE 2017).

In sum, the absence of topics that connect military issues with the fight against organised crime and terrorism points to the CDS's disagreement with the multidimensional security perspective, ${ }^{11}$ while the presence of issues related to geopolitics and concerns over potential attacks by extra-regional powers is a sign that deterrent cooperation is a locus of the CDS's activities.

Table 2: The activities of South American security institutions

\section{Multidimensional security agenda - internally focused military missions}

- Police Officer roles: CDS explicitly opposed holding activities related to public security missions.

- Fire-fighter roles: Diverse activities on the role of the military in natural and human-driven disasters.

- Peacekeeper roles: Meeting of contributors to MINUSTAH.

Cooperative security agenda - Externally-oriented military missions, limited to intra-regional conflicts and regional peace.

- $\quad$ South American Report on Defence Expenditure and Military Inventories (CEED)

Advanced Course for South American Defence (CAd-Sul)

Humanitarian International Law and Human Rights Course.

National defence - Externally-oriented military missions for extra-regional threats.

- $\quad$ Prospective Study South America 2025 (CEED)

- Advanced Course for South American Defence (CAd-Sul)

- South American Defence Education course

- South America in the International Security Context, ESUDE course.

Source: Developed by the author. 


\section{Contradictions between the activities of the CDS and the policies of its members}

The analysis of CDS activities in the previous section reveals a coherent approach to regional security based on a defence-oriented perspective. Nonetheless, the concept of deterrent cooperation did not take hold among South American nations, and no new regional defence identity was built. This failure has not gone unnoticed. Medeiros (2013, 2017), for example, has argued that this strategic formulation is a left-wing perspective influenced by Venezuela, and incompatible with the region's reticence to establish defence integration commitments with operational implications. By contrast, I argue that, while Venezuela supported the notion of deterrent cooperation, other countries exerted a greater influence over its formulation. Specifically, I have argued elsewhere that the CDS represents a convergence between Argentina's and Brazil's visions of autonomous regional defence (Vitelli 2015) - specifically, Argentina's strategic culture of prohibiting the armed forces from undertaking domestic missions, and Brazil's tradition of strategic autonomy, expressed in its National Defence Strategy, a document that featured the potential employment of its armed forces to counter a superior power threatening Brazil's territorial integrity and sovereignty in the Amazon region, a clearly traditional external defence concern.

However, this circumstantial convergence between Argentina and Brazil's defence identities contrasts with the deeper regional trend analysed in this article, namely the use of military resources for domestic purposes, particularly public security. This created a paradox for the CDS: while an important part of its agenda advocated an external defence-oriented security concept, most countries in the region - including Argentina (Saín 2017) and Brazil (Mathias et al 2016) - were already reformulating their defence policies to include domestic roles, particularly Fire Fighter and Police Officer functions.

In 2016, a widely cited regional report on defence and security, RESDAL Atlas (Donadío 2016), included information on which countries' armed forces undertook four types of public security tasks: citizen security, including the prevention of criminal activities, public order, patrolling, and riot control; preventive or repressive actions against crimes on borders; actions against organised crime and drug-trafficking; and control of prison perimeters. UNASUR members employing their armed forces in three or four of those ways include Brazil, Colombia, Ecuador and Venezuela, forming a group of countries making extensive use of their militaries for public security missions. Secondly, those countries involving their militaries in two of the public security missions include Argentina, Bolivia, Paraguay, Peru and Uruguay Guyana and Suriname employ their armed forces in respect of gun control, narcotics, and organised crime. Only Chile refrains from involving the military in public security-related missions. A similar situation exists on the rest of the continent, where, except for Panamá and Costa Rica - which do not have armed forces - all countries employ their military for at least three of the public security missions.

In other words, although countries like Argentina, Brazil, Ecuador and Venezuela expressed their support for preparing the armed forces primarily for countering external threats to natural resources, possibly signalling their opposition to a perception of 
regional security aligned with US interests, they also increased the use of the military for internal missions, often related to public security.

Table 3: Countries employing their armed forces for public security-related missions

\begin{tabular}{|c|c|c|c|c|c|}
\hline & & Citizen Security & Crimes on Borders & TOC & Prison Perimeters \\
\hline \multirow{12}{*}{ 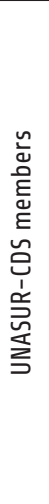 } & Argentina & - & $x$ & $x$ & - \\
\hline & Bolivia & - & $x$ & $x$ & - \\
\hline & Brazil & $x$ & $x$ & $x$ & $X^{12}$ \\
\hline & Chile & - & - & - & - \\
\hline & Colombia & $x$ & $x$ & $x$ & - \\
\hline & Ecuador & $x$ & $x$ & $x$ & - \\
\hline & Guyana & No Data & No Data & $x$ & No Data \\
\hline & Paraguay & - & $x$ & $x$ & - \\
\hline & Peru & - & $X$ & $x$ & - \\
\hline & Suriname & No Data & No Data & $x$ & No Data \\
\hline & Uruguay & - & $x$ & - & $x$ \\
\hline & Venezuela & $x$ & $x$ & $x$ & $x$ \\
\hline \multirow{9}{*}{ 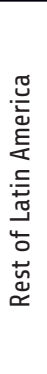 } & Costa Rica & Not Applicable & Not Applicable & Not Applicable & Not Applicable \\
\hline & Cuba & - & - & $x$ & - \\
\hline & Dominican Rep. & $x$ & $x$ & $x$ & - \\
\hline & El Salvador & $x$ & $x$ & $x$ & $x$ \\
\hline & Guatemala & $x$ & $x$ & $x$ & $x$ \\
\hline & Honduras & $x$ & $x$ & $x$ & $x$ \\
\hline & Nicaragua & $x$ & $x$ & $x$ & - \\
\hline & Panamá & Not Applicable & Not Applicable & Not Applicable & Not Applicable \\
\hline & Mexico & $x$ & $x$ & $x$ & - \\
\hline
\end{tabular}

CDS activities were associated with the Defender function - even if not all members equally supported this prioritisation - and this also featured in the discourse of prominent leaders, such as the former Brazilian chancellor and defence minister Celso Amorim, his predecessor Nelson Jobim, and the Argentine president Cristina Kirchner (Medeiros Filho 2013). The notion of deterrent cooperation was also supported by UNASUR officials, particularly its secretary-general, Alí Rodríguez; CEED's executive director, Alfredo Forti; and ESUDE's executive secretary, Antonio Ramalho. However, by examining actual policies pursued by members of UNASUR for the deployment of their armed forces, it can be argued that the consensus on a defence-oriented South American security perspective may have been overstated.

\section{Conclusion}

The evolution of regional security cooperation in Latin America since the Cold War reflects the emergence of an exclusive focus on non-state, transnational threats, and the involvement of armed forces in the battle against those threats. It also reflects an attempt 
to resist the narrative that Latin American countries are safe from (or lack the power to resist) great power rivalry or superpower domination. While ideological differences and persistent mistrust among South American partners may have hindered the consolidation of deterrent cooperation, I argue that it faced a more fundamental obstacle, namely the persistent inability or failure of these countries to think about military roles in terms of external defence.

Considering US influence on hemispheric institutions and the Perry Center's active role in socialising Latin American security and defence officials in the multidimensional security perspective, it may seem reasonable to conclude that the increasing focus on 'new threats' is a consequence of US policy, and another sign of its military hegemony over the region. While the relationship between Latin American defence policies and Washington's post-Cold War influence is an interesting topic for further research, I prefer to stress domestic and structural factors associated with the regional tendency that favours domestic security roles for the armed forces, leaving little space for traditional or conventional defensive roles. Indeed, apart from hypothetical conflicts with neighbouring countries, Latin American militaries lack the tradition to prepare for external defence threats, particularly from more powerful countries. Different factors are involved in this 'chronic inattentiveness to defence' (Pion-Berlin 2016), though it is difficult to know which elements operate as causes and which as consequences, in a way that it might be more reasonable to consider them as embedded in a relation of mutual construction. For the sake of clarity, however, I will address them separately in the remainder of these closing remarks.

First, Latin American armed forces have a long history of looking inside the borders to define their roles. Despite the many nuances that characterise each country's militaries, a general statement about the tendency to play domestic roles can be made. The armed forces in Latin America have always been Fire Fighters, Police Officers and even political parties rather than Defenders. Moreover, whenever they did prepare for an external role, the enemy was just across the border. More than three decades of the peaceful resolution of pending disputes and confidence-building measures have relativized the traditional loci of military doctrines related to external defence. Paradoxically, the achievement of a zone of peace may have had the unintended consequence of reinforcing the strategic cultural trait of the region's armed forces to scrutinise internal politics and to intervene whenever they understand that the national security is at stake, resulting in a threat to democracy and the rule of law. Pragmatic and uninformed civilian elites play their role by resorting to military solutions in order to prove to voters that results are being achieved, thereby securing the next elections.

An additional domestic factor impeding a defence policy oriented to deterring extra-regional powers is the ideological conservatism of Latin American militaries, the majority of which still operate under a Cold War mentality. The fact that the concept of deterrent cooperation was formulated by governments belonging to different degrees of the left-wing spectrum may have reinforced the structural reluctance to think about defence in external terms. Moreover, while some countries refrained from putting a name to a potentially threatening extra-regional power, others, particularly Venezuela, were explicit 
about an enmity that contradicts local loyalties. The combination of a leftist discourse and mistrust towards the USA directly confronted the core of Latin American militaries' ideology, even when it also referred to strategic autonomy, a supposed military value.

On the other hand, there are structural impediments to a joint defence policy as well. The first is a dependence on great powers as arms suppliers. A defence concept based on the deterrence of a powerful extra-regional state creates a conflict with those countries whose approval is required to purchase military equipment. This dependency is not only a military one. In fact, the very countries meeting the criteria for posing potential external threats are increasingly becoming leading trade and investment partners, thereby creating a paradox for both foreign policy and economic policy. Moreover, the resources needed to develop a credible deterrent against powerful countries are much more expensive than the military gear required for playing the roles of Fire Fighter and Police Officer. More importantly, with each technological revolution, military asymmetry for underdeveloped countries increases still further.

The current international security scenario is very different from the early 1990s, when the multidimensional security perspective began to take shape. The demise of the Soviet Union introduced a brief period of optimism about an end to large-scale conflict, which was first gainsaid by the wars in the former Yugoslavia and Rwanda, and further challenged by $9 / 11$. Fifteen years after the start of the War on Terror, the strategic scenario appears bleaker, not only because of the failure to end terrorism but also because of the deterioration in great power relations. While at the end of the $20^{\text {th }}$ century it was sensible to believe that Latin American countries did not face external, geopolitical dynamics of insecurity, the present outlook is a lot gloomier in terms of great power competition, which usually plays itself out on the territories of developing countries.

Defence establishments in Latin America are experiencing difficulties in interpreting current great power discord and its possible military impacts on the region. Domestic traditions of relinquishing defence against eternal threats and concentrating on internal security are reinforced by the structural constrains that inhibit defence policies for dependent countries. Both military and civilian experts and decision-makers seem to find it difficult to think creatively about what kind of defence strategy is possible in an age of overwhelming asymmetries in military technology. The complexity of the strategic environment demands a partnership between civilians and the military aimed at rethinking and transforming the cultural and structural factors that are precluding Latin American countries from developing coherent defence policies.

\section{Notes}

1 While this article identifies the existence of competing views between two regional cooperation institutions operating in the same region, the proliferation and overlapping of regional cooperation initiatives is not its main focus. Instead, the simultaneous existence of hemispheric and south American security institutions is identified as the expression of competing views on defence and armed forces missions. For thorough contributions on the subject of regional cooperation institutions, see Nolte (2018), Nolet and Comini (2016) and Weiffen et al (2013).

2 This institution was known as the CHDS until it was renamed after US Defence Secretary William J Perry 
in 2013. Today, is official name is the William J. Perry Center for Hemispheric Defence Studies, and the accepted short form is the Perry Center.

3 Latin American cooperation and integration initiatives are often criticised for their thin institutionalization - particularly when compared with European institutions - and their limited powers to influence members' policies, partly due to countries' strong commitments to national sovereignty. While those are interesting arguments and lines of research. I believe they often preclude other relevant questions, regarding regional cooperation as well as related topics such as the one explored in this article. Thus, given that it deals with a broader tendency in the security and defence policies of Latin American countries rather than the limitations of regional cooperation, the question of whether hemispheric and South American institutions have effectively influenced defence policies is not explicitly addressed.

4 See Martinez and Lyra (2015) for an in-depth analysis of how the establishment of councils for dealing with the drug problem and public security represents an attempt to de-securitize drug trafficking by UNASUL.

5 This section is based on an analysis of OAS Secretary-Generals' reports and CHS annual reports from 2005 to 2016, with the generous help of of Laura Donadelli (Ph.D. candidate at 'San Tiago Dantas' Graduate Program in IR). The former is available at http://www.oas.org/es/centro_informacion/informe_anual.asp, and the latter at http://www.oas.org/es/council/CSH/documentation/InformespresCSH.asp

6 Candidates who do not qualify for a graduate programme can take the same course as a diploma programme.

7 The rest are Civil-Military Relations: Theory, Strategic Decision Making, Civil-Military Relations: Practice, Strategic Leadership, International Law in Latin America, Comparative Politics of the Developing Countries: Latin America and the Caribbean.

8 The data on the Perry Center in this section was obtained from the Center's annual reports, available at http://www.williamjperrycenter.org/publication-types/annual-quarterly-publications.

9 Its 2012 syllabus had as a subtitle the unmistakable phrase 'Responses to Transnational Organized Crime,' a direct reference to a new threats issue.

10 This section is based on a previous study of official CDS documents. All of them can be accessed by sending an email to basededadoscds@gmail.com. For a detailed analysis of CDS activities, see Vitelli $(2016,2017)$.

11 Saint-Pierre (2011) noticed the deliberate exclusion of multidimensional security issues in the CDS's early stages.

12 The 2016 edition of the RESDAL Atlas does not list Brazil as a country that employs its military for controlling prison perimeters. However, I decided to include Brazil in view of a government decision in January 2017 to use the army for inspections of state prisons.

\section{References}

Bartolomé, M. 2013. 'Más allá del Crimen Organizado: a Reformulación del Concepto Insurgencia y su Impacto en el Entorno Estratégico Sudamericano'. Austral: Revista Brasileira de Estratégia e Relações Internacionais 2 (3): 47-77.

CEED. 2012. 'Informe Preliminar del CEED al CDS Acerca de los Términos de Referencia para los Conceptos Seguridad y Defensa en la Región Suramericana.' Buenos Aires. At http://www.ceedcds. org.ar/Espanol/09-Downloads/INFORME_CONCEPTOS_SEG_DEF.pdf. [Accessed on 24 March 2014].

Donadelli, L M. 2016. 'Segurança na América do Sul: Uma Abordagem Histórico-Conceitual' Master's Dissertation, UNESP-UNICAMP-PUCSP, Brazil.

Duarte Villa, R A. 2014. 'O Paradoxo da Macrossecuritização: Quando a Guerra ao Terror não Securitiza outras ‘Guerras’ na América do Sul.' Contexto Internacional 36 (2): 349-383. 
ESUDE. 2016. 'América del Sur en el Contexto de Seguridad Internacional. Quito. At http://esude-cds.unasursg.org/index.php/academia/cursos/203-esude-ame-rica-del-sur-en-el-contexto-de-seguridad-internacional. [Accessed on 3 April 2017].

2017. 'Plan Del Módulo 1: Escenarios Contemporáneos de Seguridad Internacional: Implicaciones para una Visión Regional de Seguridad y Defensa.' ESUDE. Quito. At http://esude-cds. unasursg.org/index.php/academia/cursos/509-esude-america-del-sur-en-el-contexto-de-seguridad-internacional-2. [Accessed on 3 April 2017].

Forti, A. 2014. La Defensa y los Recursos Naturales en Suramérica Aportes para una Estrategia Regional. Buenos Aires. At http://www.ceedcds.org.ar/Espanol/09-Downloads/DEF-RRNN-ALFREDO-FORTI.pdf. [Accessed on 11 October 2014].

Frenkel, A and N Comini. 2017. 'UNASUR beyond Brazil: Argentina's Position in Support of the South American Defense Council'. Revista Brasileira de Politica Internacional 60 (1): 1-20

Fuccille, A. 2016. 'La construcción de un nuevo modelo de seguridad en América del Sur: una perspectiva desde Brasil.' Anuario Latinoamericano - Ciencias Políticas y Relaciones Internacionales 3: 169-182.

Inter-American Defense Board (IADB). 2016. Inter American Defense Board Annual Report. Washington D.C. At http://www.colegio-id.org. [Accessed on 17 March 2017].

Inter-American Defense College (IADC). 2016. 'Course Catalog and Student Handbook.' Washington, D.C. At http://www.colegio-id.org/assets/class-57-catalog---2017.07.06-(eng)---final.pdf [Accessed on 19 March 2017].

Malamud, A and J C Rodriguez. 2014. 'A Caballo entre la Región y el Mundo: El Dualismo Creciente de la Política Exterior Brasileña.' Desarrollo Económico 54 (212): 63-78.

Martinez, E, D Morales and M P O de Lyra. 2015. 'O Processo de Dessecuritização do Narcotráfico na Unasul.' Contexto Internacional 37 (2): 661-691.

Mathias, S K, B S Campos and L F S Santos. 2016. 'Política militar del Gobierno de Rousseff: reflexiones sobre la actuación de las Fuerzas Armadas en las UPP y la MINUSTAH.' Íconos - Revista de Ciencias Sociales 55: 115-138.

Medeiros Filho, O. 2013. 'Em Busca de uma Identidade Regional de Defesa: Considerações sobre a Estratégia de Dissuasão Extrarregional Sul-Mericana.' Revista Brasileira de Estudos Estratégicos 1 (3): 49-70.

2017. 'A South American Defence Structure: Problems and Prospects.' Contexto Internacional 39 (3): 673-689.

Merke, F. 2015. 'Neither Balance nor Bandwagon: South American International Society Meets Brazil's Rising Power.' International Politics 52 (2): 178-192.

Nolte, D. 2018. 'Costs and Benefits of Overlapping Regional Organizations in Latin America: The Case of the OAS and UNASUR.' Latin American Politics and Society 60 (1): 128-53.

Nolte, D and N M Comini. 2016. 'UNASUR: Regional Pluralism as a Strategic Outcome.' Contexto Internacional 38 (2): 545-565.

Nolte, D and V Mijares. 2018. 'Regionalismo Posthegemónico En Crisis. ¿Por Qué La Unasur Se Desintegra?' Foreign Affairs Latinoamérica 18: 105-12.

Pion-Berlin, D. 2016. Military Missions in Democratic Latin America. New York: Palgrave Macmillan. 
Realuyo, C. 2015. 'The Future Evolution of Transnational Criminal Organizations and the Threat to U.S. National Security.' Perry Center Ocasional Paper. William J. Perry Center for Hemispheric Defense Studies. Washington, DC. At https://www.academia.edu/15972830/The_Future_Evolution_of_Transnational_Criminal_Organizations_and_the_Threat_to_U.S._National_Security. [Accessed on 16 September 2017].

Saín, M F. 2017. 'Fuerzas Armadas y Narcotráfico: La «lenta» Militarización Del Control Del Narcotráfico En Argentina (2011-2017). Paper delivered at XIII Congreso Nacional de Ciencia Política. Buenos Aires, Argentina, 2-5 August 2017.

Saint-Pierre, H L. 2011. 'Defesa' ou 'Segurança'? Reflexões em torno de Conceitos e Ideologias' Contexto Internacional 33 (2): 407-433.

2012. 'El Concepto de la Seguridad Multidimensional: Una Aproximación Crítica.' In S Alda

Mejías and V Gómez Ricaurte (eds), El Concepto y las Relaciones Multilaterales de Seguridad y Defensa en el Contexto de la UNASUR. Madrid: Instituto Universitario General Gutiérrez Mellado, pp. 19-38.

Shemella, P. 2006. 'The Spectrum of Roles and Missions of the Armed Forces.' In T C Bruneau and S D Tollefson (eds), Who Guards the Guardians and How? Democratic Civil-Military Relations. Houston: University of Texas Press, pp. 122-42.

Soares, S A. 2011. 'Contendores Apaziguados ou Partícipes da Cooperação? As Percepções sobre Ameaças e Cooperação nas Políticas de Defesa de Argentina, Brasil e Chile na Década de 1990.' In M A Guedes de Oliveira (ed), Comparando a Defesa Sul- Americana. Recife: Editora Universitária UFPE.

Soares, S A and R C Lima. 2013. 'No Limbo da Dissonância: Argentina e Brasil no Campo da Defesa.' In C A do Carmo (ed), Relações Internacionais: Olhares Cruzados. Brasília: FUNAG, pp. 315-350.

Soares, S A, and S K Mathias (eds). 2003. Novas Ameaças: Dimensões e Perspectivas. Desafios para a Cooperação em Defesa entre Brasil e Argentina. São Paulo: Sicurezza.

Spektor, M. 2010. 'Ideias de Ativismo Regional. a Transformação das Leituras Brasileiras da Região.' Revista Brasileira de Política Internacional 53 (1): 25-44.

Tickner, A and M Herz. 2012. 'No Place for Theory? Security Studies in Latin America.' In A Tickner, O Waever and D L Blaney (eds), Thinking International Relations Differently. London: Routledge, pp. 92-114.

Vaz, A C, A Fuccille and L P Rezende. 2017. 'UNASUR, Brazil, and the South American Defence Cooperation: A Decade Later.' Revista Brasileira de Política Internacional 60 (2): 1-21.

Vitelli, M. 2015. 'Argentina, Brasil y la Defensa en América del Sur. Las Identidades Estratégicas y la Seguridad Regional.' Cuadernos de Política Exterior Argentina (CERIR) 121: 1-44.

Vitelli, M. 2016a. 'La identidad estratégica argentina y el ascenso de Brasil. las bases ideacionales de una política de defensa cooperativa.' Revista de Relaciones Internacionales, Estrategia y Seguridad 11 (2): 271-289.

Vitelli, M. 2016b. 'Comunidad e Identidad en la Cooperación Regional en Defensa: Entendimientos en Conflicto sobre Pensamiento Estratégico en el Consejo de Defensa Sudamericano.' Revista Da Escola de Guerra Naval 22 (2): 233-260.

Vitelli, M. 2017. 'The South American Defense Council: The Building of a Community of Practice for Regional Defense.' Revista Brasileira de Política Internacional 60 (2): 1-17. 
Weiffen, B, L Wehner and D Nolte. 2013. 'Overlapping Regional Security Institutions in South America: The Case of OAS and UNASUR.' International Area Studies Review 16 (4): 370-389.

\section{Acknowledgments}

For this research, the author has received funding from Fundação de Amparo à Pesquisa do Estado de São Paulo (2015-13291-9).

\section{About the author}

Marina Gisela Vitelli holds a Ph.D. in International Relations from the National University of Rosario, Argentina, and has completed post-doctorate research in International Relations with the San Tiago Dantas postgraduate programme (UNESP- UNICAMPPUCSP), with a grant from the São Paulo Research Foundation (FAPESP). She is a Visiting Professor at EPPEN-UNIFESP (2018-2020), and a Professor at San Tiago Dantas. She is also a researcher for the Institute of Public Policies and International Relations (IPPRI-UNESP), and the Defence and Security Study Group (GEDES). She is co-editor of the Dicionário de Segurança e Defesa (2018, Editora UNESP). Her current research interests are Latin American civil-military relations, military missions, and regional defence cooperation. 


\title{
A Impossibilidade de uma Política de Defesa nas Américas? Comparando os Conceitos de Segurança Hemisférica e Sul-Americana e os Papéis Militares
}

\begin{abstract}
Resumo: Este artigo analisa as perspectivas conflitantes de segurança das iniciativas de cooperação em defesa do hemisfério e da América do Sul. Enquanto a Organização dos Estados Americanos (OEA) se concentra no crime organizado e no terrorismo, reforçando os papéis de segurança interna das forças armadas, o Conselho de Defesa Sul-Americano (CDS) prioriza as questões tradicionais de defesa nacional, defendendo papéis militares defensivos externos. Apesar de sua aparente consistência, o conceito de cooperação dissuasiva não se consolidou. Enquanto a literatura interpreta esse fracasso como um problema de cooperação, argumentamos que isso se deve a uma tendência regional mais profunda: a tendência de negligenciar a defesa externa em favor de papéis de segurança interna para as forças armadas. Depois de estabelecer uma estrutura conceitual sobre os papéis militares, mostramos como as duas perspectivas definem as atividades das organizações concorrentes. Em seguida, abordamos o conflito entre o conceito de segurança do CDS e as políticas de segurança dos membros. Finalmente, discutimos os obstáculos domésticos e estruturais às políticas de defesa da América Latina.

Palavras chave: América do Sul; defesa; segurança; missões militares; novas ameaças.
\end{abstract}

Received on 17 January 2019, and approved for publication on 1 April 2019. 